JAMP: Jurnal Adminitrasi dan Manajemen Pendidikan

Volume 2 Nomor 3 September 2019, Hal : 156-166

Tersedia Online di http:/journal2.um.ac.id/index.php/jamp/

ISSN 2615-8574 (online)

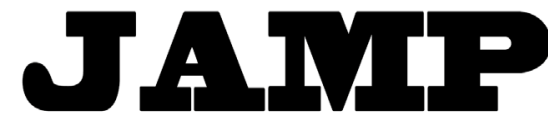

JURNAL ADMINISTRASI DAN MANAJEMEN PENDIDIKAN

\title{
PENAKSIRAN NILAI ASET DAN MANAJEMEN ASET DI SEKOLAH MENENGAH KEJURUAN
}

\author{
Ferdinand Andreas Riovaldo \\ Maisyaroh \\ Asep Sunandar \\ Universitas Negeri Malang, Jl. Semarang No. 565145 \\ E-mail: nandferdi0@gmail.com.
}

\begin{abstract}
The purpose of this research is to; Calculating the estimated value of current assets in SMK Muhammadiyah 7 Gondanglegi; Calculating the estimated value of fixed assets in SMK Muhammadiyah 7 Gondanglegi; Calculating the estimated value of the asset is not fixed in SMK Muhammadiyah 7 Gondanglegi; Know the asset management in SMK Muhammadiyah 7 Gondanglegi. To achieve that goal this research is implemented by a descriptive method. The data collection techniques used are by observation methods, documentation and interviews. While the research object is done in SMK Muhammadiyah 7 Gondanglegi. The analytical techniques used are descriptive analysis by data on all assets owned by the school, calculating the value of the assets and reduced by the depreciation rate, and then the value of the asset owned by the school. The results of this study indicate that; Assets owned by SMK Muhammadiyah 7 Gondanglegi belong to current assets, fixed assets, and intangible assets; Based on the results of the study is known that the estimated tangible assets owned by the school is $\mathrm{Rp} 224,474,037.00$. Estimated value of electronic category

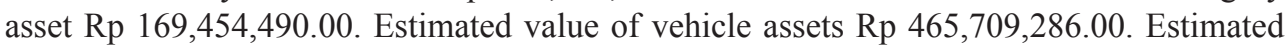
value of land and building assets Rp. 57,380,000,000.00.
\end{abstract}

Keyword: Value, Assets, and Asset Management.

\begin{abstract}
Abstrak: Tujuan dari penelitian ini untuk; Menghitung taksiran nilai aset lancar di SMK Muhammadiyah 7 Gondanglegi; Menghitung taksiran nilai aset tetap di SMK Muhammadiyah 7 Gondanglegi; Menghitung taksiran nilai aset tidak tetap di SMK Muhammadiyah 7 Gondanglegi; Mengetahui manajemen aset di SMK Muhammadiyah 7 Gondanglegi. Untuk mencapai tujuan tersebut penelitian ini dilaksanakan dengan metode deskriptif. Adapun teknik pengumpulan data yang digunakan adalah dengan metode observasi, dokumentasi dan wawancara. Sedangkan objek penelitian dilakukan di SMK Muhammadiyah 7 Gondanglegi. Teknik analisis yang digunakan adalah analisis deskriptif dengan mendata semua aktiva yang dimiliki sekolah, menghitung nilai aset dan dikurangi dengan nilai penyusutan, dan selanjutnya manaksir nilai aset yang dimiliki sekolah. Hasil dari penelitian ini menunjukan bahwa; Aset yang dimiliki SMK Muhammadiyah 7 Gondanglegi tergolong dalam aktiva lancar, aktiva tetap, dan aktiva tak berwujud; Berdasarkan hasil penelitian ini diketahui bahwa taksiran aset berwujud yang dimiliki sekolah yaitu $\mathrm{Rp} 224.474 .037,00$. Taksiran nilai aset katagori elektronik Rp 169.454.490,00. Taksiran nilai aset kendaraan Rp 465.709.286,00. Taksiran nilai aset tanah dan bangunan Rp. 57.380.000.000,00.
\end{abstract}

Kata Kunci : Nilai, Aset, dan Manajemen Aset.

Dalam bidang pendidikan aset merupakan bagian dari kekayaan yang dimiliki oleh suatu sekolah. Kekayaan yang dimaksut disini yaitu berupa gedung, tanah, kas, surat berharga, hak cipta dan lain sebagainya. Dengan adanya aset sekolah ini dapat membantu dalam menjalankan kegiatannya. Akan tetapi jika suatu aset yang dimiliki sekolah tidak di inventaris dan dirawat dengan baik maka akan menghambat kegiatan-kegiatan yang ada di sekolah. Menurut Wahjosumidjo (2011:197), terdapat 
lima hal mendasar tugas dan kewajiban yang menentukan keberhasilan kepala sekolah, yaitu program pengajaran, kesiswaan, para guru, tenaga fungsional yang lain dan tenaga administrasi, sarana dan prasarana sekolah, dan hubungan atau kerjasama antara sekolah dengan masyarakat (Juharyanto, Sultoni, 2019; Juharyanto, 2017). Dari penjelasan tersebut diketahui bahwa salah satu keberhasilan kepala sekolah dalam pengelolaan sarana dan prasarana yang merupakan bagian dari aset sekolah. Selain itu, pendapat Wahjosumidjo (2011:458), "kepala sekolah memiliki tanggung jawab utama yang berkaitan dengan fasilitas pendidikan, yaitu (1) Perencanaan bangunan sekolah (2) Kegiatan dan perawatan sekolah. Merencanakan fasilitas yang baru maupun yang diperbarui, melibatkan guru, siswa, dan masyarakat, sehingga fasilitas sekolah dirasakan bermanfaat, dapat dipahami dan fleksibel. Sedangkan pemeliharaan sebuah sekolah diharapkan menciptakan suatu lingkungan yang kondusif untuk proses belajar mengajar"

Dari penjelasan di atas dapat disimpulkan bahwa kepala sekolah juga memegang peran penting dalam perencanaan gedung-gedung sekolah agar peserta didik dapat terlayani dengan fasilitas baik, ditunjang juga dengan pemeliharaan aset agar proses belajar mengajar dapat berjalan dengan baik.

Salah satu aset yang sering kita lihat di sekolah salah satunya yaitu gedung, kendaraan, tanah. Oleh karena itu, dalam pengelolaan aset sekolah membutuhkan perhatian yang lebih dikarenakan dalam proses pengaadan membutuhkan waktu dan proses yang lama. Aset juga berkaitan dengan sarpras sekolah dimana sarpras tersebut merupakan bagian dari aset yang dimiliki sekolah yang dapat menunjang proses belajar mengajar, sedangkan aset merupakan suatu kekayaan yang dimiliki sekolah dan memberikan manfaat dimasa yang akan datang.

Agar aset yang dimiliki sekolah dapat terkelola, maka perlu diadakan penilaian aset setiap tahun secara teratur. Penilaian dilakukan sebagai wujud pelaporan dan transparansi asset sekolah/yayasan berdasarkan UU Yayasan Nomor 16 Tahun 2001. Selain itu, dapat melihat seberapa besar keberhasilan kepala sekolah dalam memimpin sekolah khususnya untuk memenuhi kebutuhan sekolah. Informasi ini dapat membantu meningkatkan kinerja kepala sekolah dalam hal pengelolaan aset yang dimiliki dalam rangka meningkatkan mutu pendidikan. Setiap waktu nilai aset akan selalu berubah diikuti dengan pertumbuhan ekonomi suatu daerah sekolah tersebut. Inflasi dan deflasi dalam suatu negara tentu akan mengakibatkan aset yang dimiliki sekolah naik sebaliknya jika mengalami deflasi maka nilai aset akan turun. Menurut pedoman teknis pengelolaan barang milik daerah (PTPBMD) (2008:84), dalam penatausahaan barang terdapat tiga kegiatan, yaitu "(1) Pembukuan, (2) Inventarisasi, dan (3) Pelaporan". Kegiatan pembukuan adalah melakukan pendaftaran dan pencatatan barang yang masuk ke sekolah. Berdasarkan Undang-undang Nomor 16 Tahun 2001 mengenai yayasan, pada pasal 48 ayat (1) dan (2) dinyatakan bahwa:

“(1) pengurusan wajib membuat dan menyimpan catatan atau tulisan yang berisi keterangan mengenai hak dan kewajiban serta hal lain yang berkaitan dengan kegiatan usaha yayasan; (2) Selain kewajiban sebagai mana dimaksud dalam ayat

1 , pengurus wajib membuat dan menyimpan dokumen keuangan yayasan berupa bukti pembukuan dan data pendukung administrasi keuangan."

Selanjutnya diadakan kegiatan inventarisasi, yaitu; "kegiatan atau tindakan untuk melakukan penghitungan, pengurusan, penyelenggaraan, pengaturan, pencatatan data dan pelaporan barang milik Negara" (PTPBMD, 2008:85). Pada tahap ini sekolah melakukan penilaian terhadap seluruh aset yang dimiliki sekolah. Setelah melakukan inventarisasi, kegiatan selanjutnya yaitu pelaporan. "pengguna menyampaikan laporan penggunaan barang semesteran, tahunan dan lima tahunan kepada kepala daerah melalui pengolaan" (PTPBMD, 2008:87). Adapun tujuan penaksiran nilai aset ini, peneliti bermaksud membantu sekolah dalam mengetahui jumlah aset yang dimiliki dengan cara menaksir. Dimana kegunaan penaksiran ini salah satunya dapat melihat seberapa besar keberhasilan kepala sekolah dalam memimpin sekolah khususnya untuk memenuhi kebutuhan sekolah. Informasi ini dapat membantu meningkatkan kinerja kepala sekolah dalam hal pengelolaan aset yang dimiliki dalam rangka meningkatkan mutu sekolah.

Permasalahan yang terjadi saat ini di lapangan sekolah belum terbiasa dalam melakukan pengukuran nilai aset. Sekolah sekarang kebanyakan hanya melakukan inventaris barang-barang yang dimiliki. Pentingnya peranan aset dan besarnya dana yang dibutuhkan untuk memperoleh aset tetap tersebut, 
maka dibutuhkan suatu pengukuran yang baik dan benar terhadap setiap aset tetap yang dimiliki perusahaan atau sekolah, yang mencakup penentuan dan pencatatan harga perolehan, penyusutan aset tetap, pengeluaran selama aset tetap digunakan dan penyajian aset dalam laporan keuangan. Dari hasil penelitian sistem manajeman aset sekolah menurut Nugroho (2014) bahwa sekolah dalam melakukan pendataan aset dapat dilakukan melalui sistem otomatis dan manual, sehingga sekolah dapat memberikan laporan data asset bisa berupa cetak. Sistem Manajen Aset Sekolah dapat membantu dalam pendataan aset yang dimiliki oleh suatu sekolah, serta memudahkan dalam menyampaikan laporan data aset. Dalam kegiatan usaha, aset tetap merupakan aset yang sangat penting dalam suatu perusahaan atau badan usaha. Pengadaan aset tetap harus benar-benar sesuai dengan kebutuhan sehingga investasi yang dilakukan terhadap aset tetap menjadi efektif sebagaimana planning visi dan misi sekolah. Aset yang dimiliki sekolah bisa berupa tanah, bangunan, tenaga, mesin, kendaraan, peralatan kantor, dan lainnya.

Penilaian aset sekolah merupakan salah satu hal penting dalam pengelolaan aset, karena dapat membantu pihak sekolah dalam mengambil keputusan pengadaan barang dan inventaris aset sekolah. Kegiatan ini ditujukan untuk melakukan estimasi (memperkirakan suatu nilai) dan memprediksi suatu nilai dari aset yang dimiliki dengan tujuan mendapatkan perkiraan nilainya. Menurut Sugiama (2013) "Penilaian aset yaitu proses kegiatan penilain dalam memberikan suatu estimasi atas nilai ekonomi suatu properti, baik harta berwujud (tangible assets) maupun harta tidak berwujud (intangible assets), berdasarkan hasil analisis terhadap fakta-fakta yang objectif dan relevan dengan menggunakan teknik, metode dan prinsip-prinsip penilaian yang berlaku". Berdasarkan pendapat tersebut dapat disimpulkan bahwa penilaian aset merupakan kegiatan menentukan menilai suatu barang dengan memperhatikan perekonomian di daerah suatu instansi tersebut baik yang berwujud maupun yang tidak berwujud yang dilakukan secara teliti agar dapat mengetahui nilai suatu barang.

SMK Muhammadiyah 7 Gondanglegi merupakan sekolah yang berada didaerah Gondanglegi yang memiliki berbagai aset yang menunjang proses belajar mengajar dan bermanfaat dimasa yang akan datang. Sekolah tersebut mempunyai suatu gedung baru yang dibangun pada tahun 2014 dan selesai pada tahun 2016 gedung tersebut menghabiskan biaya sekitar 3-4 Miliar. Gedung tersebut bernama Titanium Building menjadi ikon utama dari SMK Muhammadiyah 7 Gondanglegi yang memiliki tujuh lantai.

\section{METODE}

Dalam pengukuran aset sekolah dilakukan kegiatan untuk mengetahui nilai yang dimiliki oleh suatu aset, oleh karena itu prosesnya dilakukan dengan teknik deskriptif. Sejalan dengan karakteristik penelitian tersebut yaitu untuk memberikan gambaran, gejala-gejala, fakta-fakta, atau kejadian-kejadian secara sistematis dan akurat, mengenai sifat-sifat populasi atau daerah tertentu. Teknik pengumpulan data yang digunakan dalam pengukuran nilai aset adalah teknik dokumentasi, wawancara, dan observasi. Adapun teknik utama yang digunakan peneliti adalah teknik observasi dimana peneliti terjun langsung ke lapangan guna mengkaji data langsung ke tempat penelitian, apabila teknik observasi dirasa masih kurang, maka peneliti menggunakan teknik dokumentasi untuk pengumpulan data. Tahapan analisis data yang harus dilakukan dalam pengukuran nilai aset yaitu (1) Mendata semua aktiva tanpa terkecuali baik aktiva lancar, aktiva tetap maupun aktiva tidak berwujud, (2) Menggolongkan jenis aktiva yang telah terdata sesuai dengan kategorinya, (3) Memberikan harga taksiran kepada setiap aktiva yang telah didata, (4) Menghitung nilai penyusutan harta berdasarkan ketentuan yang berlaku dalam Undang-Undang Pajak. Ketentuan tersebut termuat dalam Keputusan Menteri Keuangan Republik Indonesia Nomor 138/ KMK.03/2002, dan (5) Menaksir nilai aset keseluruhan yang dimiliki oleh SMK Muhammadiyah 7 Gondanglegi kabupaten Malang. 


\section{HASIL}

\section{Paparan data aset SMK Muhammadiyah 7 Gondanglegi}

Untuk menaksir aset yang dimiliki sekolah, peneliti terlebih dahulu melakukan identifikasi aset yang dimiliki sekolah. Secara teoritis aset dikelompokan menjadi tiga yaitu aktiva lancar, aktiva tetap, dan aktiva tidak berwujud. Berdasarkan hasil penelitian di SMK Muhammadiyah 7 Gondanglegi aset yang dimiliki sekolah secara keseluruhan pada Tabel 1

Tabel 1 Identifikasi Aset SMK Muhammadiyah 7 Gondanglegi

\begin{tabular}{|c|c|c|c|c|}
\hline Aset/Aktiva & Jenis Aset/Aktiva & Jumlah & Nama aset & Keterangan \\
\hline $\begin{array}{l}\text { A k t i v a } \\
\text { Lancar }\end{array}$ & $\begin{array}{l}\text { Asuransi Dibayar } \\
\text { Dimuka } \\
\text { Sedian Bahan Habis } \\
\text { Pakai }\end{array}$ & $\begin{array}{l}5 \text { Dus } \\
2 \text { Pak } \\
2 \text { Pak } \\
5 \text { Pak } \\
5 \text { Botol } \\
28 \text { Buah }\end{array}$ & $\begin{array}{l}\text { Kertas HVS F4 } \\
\text { Spidol Hitam } \\
\text { Steples Kecil } \\
\text { Amplop Besar } \\
\text { Lem Glukol kecil } \\
\text { Kalender kecil }\end{array}$ & \\
\hline Aktiva Tetap & Mesin & $\begin{array}{l}2 \\
1 \\
1 \\
1 \\
1 \\
\\
4 \\
2 \\
1 \\
254 \\
3 \\
1 \\
1 \\
1 \\
1 \\
4 \\
3 \\
2\end{array}$ & $\begin{array}{l}\text { Gedung Pembelajaran } \\
\text { Graha Teknologi } \\
\text { Teaching Factory } \\
\text { Titanium Building } \\
\text { Ruang Guru } \\
\text { Printer Epson } \\
\text { Printer Canon } \\
\text { Mesin fotocopy Canon } \\
\text { Komputer Dell } \\
\text { Komputer LG } \\
\text { Laptop Lenovo } \\
\text { Laptop Acer } \\
\text { AC Daikin } \\
\text { AC Polytron } \\
\text { Kipas Angin } \\
\text { Wireles } \\
\text { Tv Sharp }\end{array}$ & $\begin{array}{l}1.012 \mathrm{~m}^{2} \\
512 \mathrm{~m}^{2} \\
1.200 \mathrm{~m}^{2} \\
800 \mathrm{~m}^{2} \\
110 \mathrm{~m}^{2} \\
\text { Th } 2011 \\
\text { Th } 2017 \\
\text { Th } 2017 \\
\text { Th } 2017 \\
\text { Th } 2011 \\
\text { Th } 2011 \\
\text { Th } 2016 \\
\text { Th } 2013 \\
\text { Th } 2015 \\
\text { Th } 2010 \\
\text { Th } 2010 \\
\text { Th } 2013\end{array}$ \\
\hline & Kendaraan Yayasan & $\begin{array}{l}1 \\
1 \\
1\end{array}$ & $\begin{array}{l}\text { Mobil Innova } \\
\text { Mobil Pick Up } \\
\text { Mobil Kijang K }\end{array}$ & $\begin{array}{l}\text { Th } 2013 \\
\text { Th } 2013 \\
\text { Th } 2013\end{array}$ \\
\hline $\begin{array}{l}\text { Aktiva Tidak } \\
\text { Tetap }\end{array}$ & Guru dan Pegawai & 63 & $\begin{array}{l}\text { Meja Kursi Kepsek } \\
\text { Meja Kursi Tamu } \\
\text { Meja Kursi Meeting } \\
\text { Meja Kursi Resepsionis } \\
\text { Meja Kursi Komputer } \\
\text { Meja Kursi Pegawai } \\
\text { Meja Kursi Besar } \\
\text { Lemari Arsip } \\
\text { Lemari Loker } \\
\text { Lemari Piala } \\
\text { Lemari TU } \\
\text { Orang }\end{array}$ & \\
\hline
\end{tabular}

Berdasarkan data di atas, dapat diketahui bahwa SMK Muhammadiyah 7 Gondanglegi memiliki jenis aktiva lancar yaitu persedian barang habis pakai, aktiva tetap terdiri dari tanah dan bangunan, mesin, kendaraan yayasan, dan perabot, serta aktiva tak berwujud diantaranya guru dan staff. 


\section{Taksiran Nilai Aktiva SMK Muhammadiyah 7 Gondanglegi}

Untuk mengetahui aktiva lancar dan aktiva tetap yang dimiliki sekolah, peneliti melakukan penelitian menggunakan metode penelitian observasi, yaitu peneliti langsung terjun ke lapangan dan mendata semua data informasi yang diperlukan. Pada macam-macam aktiva lancar, sekolah memiliki persediaan barang habis pakai dan barang elekronik. Peneliti melakukan pendataan terhadap aktiva terseabut dan memperoleh data yang menunjukan bahwa aktiva secara keseluruhan yang berwujud terdapat 80 item yang terdiri dari barang habis pakai dan barang elektronik. Barang-barang tersebut dibeli mulai dari tahun 2010 sampai dengan 2019. Nilai pembelian secara keseluruhan dari aktivaaktiva tersebut yaitu $\mathrm{Rp} 242.312 .800,00$. Seiring dengan berjalannya waktu aktiva-aktiva yang dimiliki mengalami penurunan sebesar Rp 17.838.763,00. Sehingga nilai aset yang tersisa pada barang-barang tersebut hanya tinggal $\mathrm{Rp} 224.474 .037,00$. Hal ini terjadi karena dalam kurun waktu beberapa tahun barang-barang tersebut mengalami penurunan nilai aset yang sejalan dengan bertambahnya usia dari aset tersebut. Sekolah masih bisa menggunakan barang-barang tersebut walaupun nilai dari suatu barang sudah tidak ada, hal ini dikarenakan barang-barang atau aset masih bisa dimanfaatkan dan memiliki nilai guna. Dapat diketahui melalui tabel 2

Tabel 2 Pengukuran Nilai Aset Lancar

\begin{tabular}{cccc}
\hline Jumlah Aset & Harga Perolehan & Penyusutan & Nilai Aset \\
\hline 80 Item & Rp 242.312.800 & Rp 17.838.763 & Rp 224.474.037 \\
\hline
\end{tabular}

Aset lancar lain yang dimiliki SMK Muhammadiyah 7 Gondanglegi yaitu barang-barang yang termasuk barang elektronik, peneliti melakukan pendataan aset berupa elektronik yang dimiliki sekolah sebanyak 42 item dengan rentan waktu pembelian tahun 2010 sampai dengan tahun 2017. Harga pembelian dari barang elektronik tersebut secara keseluruhan yaitu sebesar Rp 181.483.000,00. Setelah itu peneliti melakukan perhitungan dengan asumsi penyusutan barang 30 persen, nilai aset tersebut mengalami penyusutan sebesar Rp 12.028.510,00 sehingga sisa nilai dari aset tersebut sebesar Rp 169.454.490,00. Hal ini terjadi karena barang-barang elektronik tersebut semakin lama mengalami penurunan nilai walaupun masih bisa beroprasi dan memiliki nilai guna. Dapat diketahui melalui tabel 3

Tabel 3 Pengukuran Nilai Aset Tetap

\begin{tabular}{cccc}
\hline Jumlah Aset & Harga Perolehan & Penyusutan & Nilai Aset \\
\hline 42 Item & Rp 181.483.000 & Rp 12.028.510 & Rp 169.454.490 \\
\hline
\end{tabular}

Sebagian besar aktiva yang dimiliki oleh sekolah adalah aktiva tetap. Peneliti mendapatkan informasi data melalui metode observasi langsung ke setiap gedung sekolah. Untuk mengetahui tahun berdirinya serta anggaran yang digunakan peneliti melakukan wawancara terhadap wakil kepala sekolah dibidang sarana dan prasarana. Hal ini peneliti memperoleh data aset tetap yang dimiliki sekolah yaitu tanah, dan kendaraan. Tanah yang dimiliki sekolah terdiri dari tanah bangunan pendidikan dan bangunan pendidikan. Untuk tanah bangunan pendidikan yang diadakan pada 1994 luas tanah nya $40.000 \mathrm{~m}^{2}$ secara nominal tanah tersebut dibeli dengan harga $\mathrm{Rp} 2.000 .000 .000,00$. Kenaikan harga tanah di asumsikan selalu naik 10 persen dari harga pembelian tanah tersebut, setelah dihitung aset tanah pada tahun 2019 memiliki nilai penambah Rp 5.000.000.000,00 sehingga nilai aset tanah bangunan pendidikan sebesar Rp 7.000.000.000,00. Selain itu sekolah juga memiliki tanah rumah yang baru saja dibeli pada tahun 2017 tanah ini digunakan sementara untuk menampung kendaraan bermotor para siswa-siswi nya. Untuk tanah rumah ini miliki luas tanah $10.000 \mathrm{~m}^{2}$ secara nominal tanah tersebut dibeli dengan harga $\mathrm{Rp} 600.000 .000,00$. Kenaikan tanah yang diasumsikan 10 persen dari harga pembelian, sehingga memiliki nilai penambahan Rp 120.000.000,00 memiliki niali aset Rp 720.000.000,00. Jadi, nilai penambahan dari kedua aset tanah tersebut sebesar $\mathrm{Rp} \mathrm{5.120.000.000,00} \mathrm{dan} \mathrm{nilai} \mathrm{dari} \mathrm{kedua} \mathrm{asset}$ Rp 7.720.000.000,00. Selain kedua tanah tersebut sekolah memiliki beberapa bangunan gedung. Peneliti juga melakukan penaksiran nilai aset dari bangunan yang dimiliki. Gedung pembelajaran memiliki luas bangunan $1.012 \mathrm{~m}^{2}$, anggaran yang dikeluarkan sekolah yaitu $\mathrm{Rp} 780.000 .000,00$ bangunan tersebut memiliki nilai tambah Rp,1,950,000,000 dan memiliki nilai aset sebesar Rp 2.730.000.000,00. Gedung Graha Teknologi memiliki luas bangunan $512 \mathrm{~m}^{2}$, anggaran yang dikeluarkan sekolah yaitu Rp 1.400.000.000,00 bangunan tersebut memiliki nilai tambah Rp 1.120.000.000,00 dan memiliki nilai aset sebesar Rp 2.520.000.000,00. Gedung Teaching Factory memiliki luas bangunan $1.200 \mathrm{~m}^{2}$, 
anggaran yang dikeluarkan sekolah yaitu Rp 4.500.000.000,00 bangunan tersebut memiliki nilai tambah Rp 2.250.000.000,00 dan memiliki nilai aset sebesar Rp 6.750.000.000,00. Gedung Titanium Building memiliki luas bangunan $800 \mathrm{~m}^{2}$, gedung ini menghabiskan anggaran yang dikeluarkan sekolah yaitu Rp 26.000.000.000,00 bangunan tersebut memiliki nilai tambah Rp 10.400.000.000 dan memiliki nilai aset sebesar Rp 36.400.000.000,00. Dan yang terakhir gedung ruang guru anggaran yang dikeluarkan sekolah yaitu $\mathrm{Rp} \mathrm{900.000.000,00.} \mathrm{bangunan} \mathrm{tersebut} \mathrm{memiliki} \mathrm{nilai} \mathrm{tambah} \mathrm{Rp} \mathrm{810.000.000,00} \mathrm{dan}$ memiliki nilai aset sebesar Rp 1.710.000.000,00. Total dari nilai penambahan aset gedung tersebut yaitu Rp 16.530.000.000,00 dan total nilai aset dari bangunan sebesar Rp 50.110.000,00. Kedua aset tanah dan bangunan tersebut dimiliki oleh SMK Muhammadiyah 7 Gondanglegi untuk menunjang proses pendidikan. Dapat diketahui melalui tabel 4

Tabel 4 Pengukuran Nilai Aset Tetap

\begin{tabular}{cccc}
\hline Jumlah Aset & Harga Perolehan & Penambahan & Nilai Aset \\
\hline 7 Bangunan \& Tanah & Rp 36.180.000.000 & Rp 21.650.000.000 & Rp 57.830.000.000 \\
\hline
\end{tabular}

Aset tetap SMK Muhammadiyah 7 Gondanglegi selain tanah dan bangunan juga berupa kendaraan. Peneliti melakukan pendataan kendaraan yayasan dan kendaraan yang digunakan dalam prakter siswa terdapat 13 jenis kendaraan. Kendaraan tersebut terdiri dari 3 mobil yayasan dan 10 kendaraan bermotor, tahun dari kendaraan tersebut 2012 sampai dengan 2014. Harga perolehan dari keseluruhan aset kendaraan $\mathrm{Rp} 490.170 .000,00$. Setelah itu peneliti melakukan perhitungan dengan mengasumsikan penyusutan 30 persen, nilai aset tersebut mengalami penyusutan sebesar Rp 24.460.714,00. Sehingga sisa nilai aset kendaraan secara keseluruhan yaitu sebesar $\mathrm{Rp} 465.709 .286,00$. Walaupun nilai dari suatu aset tersebut mengalami penurunan tetapi masih bisa digunakan untuk kepetingan sekolah. Semakin lama suatu barang maka semakin menurun juga nilai dari barang tersebut.

Tabel 5 Pengukuran Nilai Aset Tetap

\begin{tabular}{cccc}
\hline Jumlah Aset & Harga Perolehan & Penambahan & Nilai Aset \\
\hline 13 Kendaraan & Rp 490.170.000 & Rp 24.460.714 & Rp 465.709.286 \\
\hline
\end{tabular}

Aset sekolah yang berupa aset tidak tetap yang dimiliki sekolah adalah aset sumber daya manusia dengan jumlah guru dan staff 63 orang. Peneliti hanya melakukan pendataan guru dan staff disekolah dikarenakan niali dari aset ini tidak dapat diukur berupa berapa ilmu yang sudah didapatkan guru dan staff mulai dari jenjang pendidikan bawah hingga jenjang pendidikan tinggi. Sehingga peneliti hanya bisa menunjukan mengnai jumlah dari keseluruhan guru dan staff yang dimiliki. Sumber daya manusia yang dimiliki sekolah dapat berubah seiring dengan kebutuhan sekolah tersebut.

\section{Manajemen Aset SMK Muhammadiyah 7 Gondanglegi}

Manajemen aset di sekolah merupakan suatu upaya dalam mengoptimalkan pemanfaatan dan penggunaan sumber daya yang dimiliki sekolah guna mencapai batas optimal fungsi suatu barang. Aset dimasukkan dalam hal ini yaitu sesuatu yang memiliki nilai dan digunakan dalam mencapai tujuan. Kebanyakan sekolah memiliki beragam aset seperti aktiva lancar, aktiva tetap, dan aktiva tidak tetap, dengan beragamnya jenis aset yang dimiliki sekolah tentu nya kepala sekolah memiliki cara tersendiri dalam memanajemen aset-aset nya sendiri. Proses pengelolaan aset di SMK Muhammadiyah 7 Gondanglegi tak lepas dari peran kepala sekolah dalam sebagai pemimpin. Kepala sekolah memberikan wewenang kepada wakil nya di bidang sarana dan prasarana agar dapat dikelola dengan baik dan teratur. Sekolah memiliki struktur organisasi dibidang sarana dan prasarana tersendiri yang dipimpin oleh bapak Drs. Suherman, beliau memiliki 2 staff dibagi untuk bagian kampus 1 dan kampus 2. Bagian kampus 1 pak Sudi bertugas untuk mengelola sarana dan prasaran yang berada di area Teaching Factory sampai dengan ruang guru, sedangkan kampus 2 pak Sunantri bertugas mengelola sarana dan prasaran bagian gedung graha teknologi sampai gedung Titanium Building. Kedua staff sarpras tersebut bertanggung jawab langsung kepada wakasek bidang sarpras dan untuk wakasek bidang sarpras bertanggung jawab langsung kepada kepala sekolah. Dalam hal ini dijelaskan juga bahwa struktur pengelolaan aset disekolah dipegang penuh oleh kepala sekolah, tetapi juga ada bagian aset tersendiri yang dipegang oleh 
waka sarpras dan dibantu oleh staff sarpras. Pengelolaan aset yang dilakukan di SMK Muhammadiyah 7 Gondanglegi dengan cara kaprok setiap jurusan membuat program pengajuan barang dan bahan guna pembelajaran, selanjutnya di ajukan ke kepala sekolah. Sedangkan pengadaan barang secara umum yang bersifat isidental langsung kepada waka sarpras. Dalam proses pengadaan sekolah mendapat bantuan bisa berupa gedung,ruang kelas, ruang praktik perserikatan dan bos.

Perawatan yang dilakukan dalam menjaga agar aset tetap dalam keadaan baik yaitu dengan cara perawatan rutin dan isidental, perawatan rutin dilakukan setiap hari seperti pengecekan barang. Sedangkan yang di dalam lab perawatan dilakukan langsung oleh kaprok masing-masing jurusan. Peserta didik diminta juga untuk turut serta menjaga aset yang dimiliki dengan cara menggunakan sesuai dengan kebituhannya dan dijaga kelasungannya agar aset dapat dipelihara dengan baik. Peserta didik tersebut menggunakan aset sekolah dibawah pembinaan dan pengawasan kaprok dimasing-masing jurusan. Dalam hal ini diketahu bahwa siswa turut berperan dalam pemeliharaan aset sebagai pemakai utama yang berhubungan langsung dengan aset yang dimiliki sekolah. Selain peserta didik, masyarakat sekitar lingkungan sekolah juga turut serta dalam menjaga aset sekolah. Peran masyarakat dalam pemeliharaan aset sekolah diantaranya adalah peran dalam menjaga keamanan sekolah, membantu perbaikan sarana sekolah dan memberikan fasilitas umum yang dibutuhkan sekolah.

Aset SMK Muhammadiyah 7 Gondanglegi merupakan atas nama perserikatan muhammadiyah dan bukan milik pribadi, kepala sekolah dalam hal ini hanya mengelola untuk keseluruhan aset yang dimiliki disekolah. Proses pertanggungjawaban sekolah terhadap yayasan yaitu melalui laporan setiap tahunnya mulai dari barang yang akan di rencakan sampai barang tersebut dihapuskan. Barang yang akan di anggarkan dilaporkan langsung kepada yayasan guna memperoleh dana dalam pengadaan, sehingga sekolah dapat terpenuhi kebutuhan-kebutuhan dalam proses pembelajaran.

\section{PEMBAHASAN}

\section{Pengukuran Nilai Aset di SMK Muhammadiyah 7 Gondanglegi}

Kata manajemen aset sekolah belum begitu dikenal oleh sekolah dibandingkan dengan manajemen sarana dan prasarana, hal ini dikarenakan sekolah lebih menggunakan kata sarana dan prasarana dari pada aset sekolah, sehingga lebih mengenal dengan kata sarana dan prasarana. Menurut sutrisna (1986) Association of Facilities Managers mengartikan manejemen sarana dan prasarana sebagai pengelolaan aset dan bangunanan bersama dengan fasilitas layanan dan orang-orang yang terkandung didalamnya ini memiliki implikasi dalam hal desain awal, pemeliharaan, administrasi sehari-hari dan pengendalian tenaga kerja, energy dan sumber daya yang terkait". Sedangkan Manajemen aset menurut Jeeva dan Baswaid dalam Sunandar (2016:20)" manajemen aset adalah sebagai pendekatan yang memadukan integrasi system operasional, kebutuhan, informasi, lingkungan dan keahlian untuk meningkatkan kinerja bisnis dimasa yang akan datang". Berdasarkan kedua penjelasan tersebut dapat disimpulkan bahwa manajemen sarpras merupakan usaha manusia melakukan manajemen fasilitas mulai dari sarpras sampai pemeliharaannya dan perbaikan aset yang dimiliki agar bermanfaat dimasa yang akan datang. Dalam hal tersebut dapat diketahui bahwa sarpras merupakan bagian dari aset sekolah. Kebanyakan sekolah hanya melakukan pendataan dan inventaris terhadap aset yang dimiliki, tetapi tidak di ukur nilai dari aset tersebut. Dari hasil penelitian disekolah, bahwa sekolah hanya melakukan pendataan dan inventaris dari barang atau aset sekolah.

Kegiatan manajemen aset bukan hanya mengenai inventaris maupun pendataan aset tetapi juga pengukuran dari nilai aset-aset tersebut. Secara teori menurut Hadinata dalam Sunandar (2016:17) asset (aset) dijelaskan sebagai barang yang dalam pengertian hukum disebut benda, yang jadi terdiri dari benda tidak bergerak dan benda bergerak, baik yang berwujud (tangible) maupun yang tidak berwujud (Intangible), yang tercakup dalam aktiva/kekayaan atau harta kekayaan dari suatu instansi, organisasi, badan usaha atau individu perorangan. Penjelasan tersebut diketahui bahwa aset merupakan kekayaan yang dimiliki suatu organisasi/lembaga, dalam hal ini aset sekolah dijelaskan sebagai kekayaan yang dimiliki sekolah baik itu aset lancar, aset tetap, dan aset tidak tetap. 
Hasil dari penelitian di SMK Muhammadiyah 7 Gondanglegi menggambarkan bahwa sekolah kurang memperhatikan nilai aset dari suatu aset, dan juga tidak memperhatikan nilai dari suatu aset yang cenderung naik dan turun. Aset yang termasuk aktiva lancar yang dimiliki sekolah seperti barang habis pakai dan katagori elektronik cenderung mengalami penurunan nilai aset. Sedangkan aset yang termasuk aktiva tetap dan aktiva tidak tetap akan mengalami kecenderungan naik. Dalam hal ini peneliti menjadikan standart dalam melakukan penaksiran nilai aset yang tertuang dalam Keputusan Menteri Keuangan Republik Indonesia Nomor 138/KMK.03/2002 tentang jenis-jenis harta yang termasuk dalam kelompok harta berwujud bukan bangunan yaitu "Harga barang mebel dan elektronik cenderung akan turun nilainya sebesar 20-50\% pertahun, harga barang berupa bangunan cenderung turun 5\% pertahun, dan harga tanah cenderung naik $10 \%$ pertahun". Penjelasan tersebut menjelaskan bahwa penurunan nilai aset sebesar 20-50 persen untuk katagori aset seperti barang habis pakai, elektronik, kendaraan yayasan, dan bangunan yang dimiliki SMK Muhammadiyah 7 Gondanglegi. Selain itu sekolah memiliki aset tetap yaitu berupa tanah yang cenderung naik, kenaikan aset tanha sekolah tersebut dipengaruhi oleh pertumbuhan ekonomi didaerah gondanglegi.

Apabila pertumbuhan ekonomi dari daerah tersebut naik maka akan mengikuti juga harga dari tanah naik, sebaliknya jika pertumbuhan ekonomi turun maka akan turun juga harga tanah didaerah tersebut. Menurut Lumbantoruan (2006:249), ada empat faktor yang harus dipertimbangkan dalam penghitungan besarnya biaya penyusutan suatu aktiva, yaitu; nilai perolehan aktiva yaitu pengeluaranpengeluaran yang dilakukan sampai aktiva yang bersangkutan siap dipakai. nilai residu yaitu nilai sisa suatu aktiva yang ditaksir pada akhir masa pemakaian aktiva di perusahaan, sifat aktiva yaitu sifat dan cara penggunaan aktiva dalam kegiatan usaha sangat berpengaruh pada penentuan besarnya biaya penyusutan, dan umur aktiva yaitu masa pemakaian aktiva dalam usaha, umur aktiva dapat dilihat dari umur teknis dan umur ekonomis. Dari penjelasan tersebut dapat disimpulakan dalam konteks dunia pendidikan, faktor yang mempengaruhi nilai penyusutan suatu aktiva, dimulai dari besarnya biaya yang dikeluarkan pada saat pengadaan barang hingga dapat dipakai. Kemudian, penyusutan yang terjadi akibat pemakaian barang, cara penyusutan tiap barang pun berbeda dipengaruhi oleh sifat dan cara penggunaan dalam suatu kegiatan. Selain itu, umur barangjuga mempengaruhi dalam menilai penyusutan. Pihak sekolah belum dalam hal ini hanya terbiasa dengan umur suatu aset yang semakin lama maka semakin berkurang nilai aset yang dimiliki.

Aktiva tetap dijelaskan pendapat Harahap dalam Sunandar(2016:25), yang menjelaskan menjelaskan jenis-jenis aktiva tetap. Terdiri dari lahan adalah bidang tanah terhampar baik yang merupakan tempat bangunan maupun yang masih kosong; bangunan gedung adalah bangunan yang berdiri di atas bumi ini baik di atas lahan/air; mesin termasuk peralatan-peralatan yang menjadi bagian dari mesin yang bersangkutan; kendaraan Semua jenis kendaraan seperti alat pengakutan, truck, grader, tractor, forklift, mobil, kendaraan roda dua, dan lain-lain; perabot dalam jenis ini termasuk perabot kantor, perabot laboratorium, perabot pabrik yang merupakan isi dari suatu bangunan; inventaris/peralatan dianggap merupakan alat-alat besar yang digunakan dalam perusahaan seperti inventaris kantor, inventaris pabrik, inventaris laboratorium, inventaris gudang dan lain-lain; prasarana di Indonesia adalah merupakan kebiasaan bahwa perusahaan mmembuat klasifikasi khusus prasarana seperti: jalan, jembatan, pagar, dan lain-lain. Dari pendapat tersebut diadaptasikan dengan hasil penelitian di SMK Muhammadiyah 7 Gondanglegi bahwa katagori aset tetap yang dimiliki sekolah yaitu katagori tanah dan bangunan yang terdiri dari Gedung Pembelajaran, Graha Teknologi, Teaching Factory, Titanium Building, dan Ruang Guru. Katagori mesin atau elektronik yaitu Printer Epson, Printer Canon, Mesin fotocopy Canon, Komputer Dell, Komputer LG, Laptop Lenovo, Laptop Acer, AC Daikin, AC Polytron, Kipas Angin, Wireles, dan Tv Sharp. Katagori kendaraan yayasan yaitu mobil inova, mobil pickup, dan mobil kijang krista. Katagori perabot yaitu Meja Kursi Kepsek, Meja Kursi Tamu, Meja Kursi Meeting, Meja Kursi Resepsionis, Meja Kursi Komputer, Meja Kursi Pegawai, Meja Kursi Besar, Lemari Arsip, Lemari Loker, Lemari Piala, dan Lemari TU. Dari bebarapa aset tetap yang dimiliki sekolah seperti tanah dan bangunan setelah melakukan perhitungan diperoleh yaitu tanah, dan kendaraan. Aset berupa tanah dan bangunan yang dimiliki SMK Muhammadiyah 7 Gondanglegi memiliki nilai aset keseluruhan Rp 57.830.000.000,00. Sedangkan nilai penambahan dari aset tanah dan bangunan sebesar 
Rp 21.650.000.000,00. Dari data di atas diketahui bahwa aset tetap katagori bangunan dan tanah yang dimiliki SMK Muhammadiyah 7 Gondanglegi memberikan gambaran bawasanya nilai dari tanah dan bangunan cenderung naik sehubung dengan perkembangan ekonomi disuatu daerah. Kenaikan tersebut tak lepas dari faktor perekonomian di daerah gondanglegi yang ditandai dengan naiknya suatu nilai aset tanah.

Penilaian atau pengukuran terhadap aset aktiva lancar dan aktiva tetap yang dimiliki SMK Muhammadiyah 7 Gondanglegi memberikan gambaran bahwa aset atau kekayaan yang dimiliki haruslah dikelola dengan baik dikarenakan aset tersebut memiliki nilai yang tinggi. Selain itu, penyusutan setiap aset juga menjadi hal yang sudah biasa terjadi mengingat dari seberapa banyak aset digunakan dan seberapa tua umur aset yang dimiliki sekolah. Hasil penelitian Sherly Maya(2012) menunjukan pengeluaran pembangunan sekolah secara tidak langsung mempengaruhi jumlah aset yang dimiliki yaitu aktiva lancar. Maka dari itu perlu upaya untuk menyeimbangkan pengeluaran aset tiap tahunnya. Sekolah dalam pengelolaan aset yaitu pemeliharaan dan pemakaian/penggunaan aset secara optimal. Sedangkan agar usia dari aset tersebut bisa panjang yaitu dengan memeliharanya dengan baik dan melibatkan warga sekolah yang berkaitan langsung dengan aset. Pemeliharaan ini bisa dengan mengontrol, membersihkan, dan memperbaiki aset yang dimiliki sekolah. Keamanan aset perlu juga di perhatikan karena aset tersebut memiliki nilai yang tinggi dan sebagai saran dan prasarana dalam menunjang kegiatan pembelajaran. Keamanan aset bisa melibatkan masyarakat sekitar maupun menunjuk staff sekolah dalam melakukan keamanan.

Hasil penelitian dalam pendataan aset tidak tetap yang dimiliki SMK Muhammadiyah yaitu aset sumber daya manusia dengan jumlah guru dan staff 63 orang. Peneliti hanya melakukan pendataan guru dan staff disekolah dikarenakan niali dari aset ini tidak dapat diukur berupa berapa ilmu yang sudah didapatkan guru dan staff mulai dari jenjang pendidikan bawah hingga jenjang pendidikan tinggi. Sehingga peneliti hanya bisa menunjukan mengenai jumlah dari keseluruhan guru dan staff yang dimiliki. Sumber daya manusia yang dimiliki sekolah dapat berubah seiring dengan kebutuhan sekolah tersebut. hal ini sesuai dengan teori yang dikemukakan oleh sunandar (2016:27) yang mendefinisikan mengenai aktiva tidak berwujud sebagai aktiva yang menggambarkan hak-hak istimewa seperti hak paten, hak cipta, franchise, goodwill.

Setiap tahunnya aset pasti mengalami penyusutan sesuai yang dijelaskan peneliti. Pada aktiva tetap, agar tidak terjadi penurunan nilai aset, maka kepala sekolah hendaklah menjaga keseimbangan aset tiap tahunnya. Salah satu usaha yang dapat dilakukan yaitu dengan menghapus aktiva yang sudah tidak layak pakai dan mengadakan aktiva yang baru. Beberapa aktiva yang di anggap rusak atau tidak terpakai dan tidak memiliki nilai aset perlu dihapus agar sekolah tidak mengeluarkan anggaran untuk perawatan.

\section{Manajemen Aset SMK Muhammadiyah 7 Gondanglegi}

Proses manajemen aset yang ada di SMK Muhammadiyah 7 Gondanglegi yang ditemukan oleh peneliti yaitu kepala sekolah melakukan pengelolaan aset yang dimiliki secara langsung. Kepala sekolah juga memberikan wewenang kepada wakil nya di bidang sarana dan prasarana agar dapat dikelola dengan baik dan teratur. Struktur organisasi dibidang sarana dan prasarana dan beliau memiliki 2 staff dibagi untuk bagian kampus 1 dan kampus 2. Pengelolaan aset yang dilakukan di SMK Muhammadiyah 7 Gondanglegi dengan cara kaprok setiap jurusan membuat program pengajuan barang dan bahan guna pembelajaran, selanjutnya di ajukan ke kepala sekolah. Sedangkan pengadaan barang secara umum yang bersifat isidental langsung kepada waka sarpras. Selain penejelasan diatas tentang manajemen aset diperkuat dengan tujuan yang terkandung dari kegiatan manajemen aset. Menurut Brown, K. etc. (2012) memberikan penjelasan tentang tujuan manajemen aset untuk mengoptimalkan potensi pengadaan pelayanan dari aset yang bersangkutan. meminimalisasi resiko dan biaya, dan meningkatkan nilai positif modal alami dan sosial dalam siklus kehidupan suatu aset. Layaknya suatu tujuan manajerial yang selalu berorientasi pada keefektifan dan keefisienan, manajemen aset juga bertujuan pada meningkatnya erektifitas dan efisiensi suatu aset. Nilai beberapa aset yang cenderung menurun mengharuskan pengelola aset cermat mcmperhatikan usia aset. Sehingga nilai efektif dari sebuah aset dapat teroptimalkan dengan baik. 
Temuan peneliti di sekolah yaitu Perawatan yang dilakukan dalam menjaga agar aset tetap dalam keadaan baik yaitu dengan cara perawatan rutin dan isidental, perawatan rutin dilakukan setiap hari seperti pengecekan barang. Peserta didik diminta juga untuk turut serta menjaga aset yang dimiliki dengan cara menggunakan sesuai dengan kebutuhannya dan dijaga kelasungannya agar aset dapat dipelihara dengan baik. Peserta didik tersebut menggunakan aset sekolah dibawah pembinaan dan pengawasan kaprok dimasing-masing jurusan. Selain itu masyarakat sekitar lingkungan sekolah juga turut serta dalam menjaga aset sekolah. Peran masyarakat dalam pemeliharaan aset sekolah diantaranya adalah peran dalam menjaga keamanan sekolah, membantu perbaikan sarana sekolah dan memberikan fasilitas umum yang dibutuhkan sekolah.

Beberapa hal diatas mengambarkan bahwa manajemen aset diperlukan sekolah agar mendukung dalam pencapaian tujuan sekolah. Manajemen aset merupakan suatu kesatuan dalam proses manajemen yang ada disekolah, oleh karena itu, pengelolaan aset yang baik dibutuhkan oleh sekolah guna proses pendidikan dapat berjalan dengan baik. Keberadaan aset yang banyak juga menjadi salah satu komponen penting dalam keberhasilan suatu organisasi atau lembaga di masa yang akan datang.

\section{SIMPULAN DAN SARAN}

\section{Simpulan}

Berdasarkan hasil penelitian yang dilakukan di SMK Muhammadiyah 7 Gondanglegi, aset yang dimiliki sekolah yaitu jenis aktiva lancar memiliki nilai aset sebesar Rp 224.474.037,00 dan memiliki nilai penyusutan aset Rp 17.838.763,00. Aset tetap yang dimiliki SMK Muhammadiyah 7 Gondanglegi secara keseluruhan memiliki nilai aset Rp 58.465.163.773,00. Dan memiliki aset tidak tetap yaitu sumberdaya manusia sebanyak 63 yang terdiri dari pendidik dan tenaga kependidikan. Proses pengelolaan aset di SMK Muhammadiyah 7 Gondanglegi tak lepas dari peran kepala sekolah dalam sebagai pemimpin. Kepala sekolah memberikan wewenang kepada wakil nya di bidang sarana dan prasarana agar dapat dikeloladengan baik dan teratur. Sekolah memiliki struktur organisasi dibidang sarana dan prasarana tersendiri yang dipimpin oleh waka sarpras beliau memiliki 2 staff. Kedua staff sarpras tersebut bertanggung jawab langsung kepada wakasek bidang sarpras dan untuk wakasek bidang sarpras bertanggung jawab langsung kepada kepala sekolah. Perawatan yang dilakukan dalam menjaga agar aset tetap dalam keadaan baik yaitu dengan cara perawatan rutin dan isidental, perawatan rutin dilakukan setiap hari seperti pengecekan barang. Pemeliharaan aset sekolah melibatkan warga sekolah dan masyarakat sekitar lingkungan sekolah.

\section{Saran}

Berdasarkan dari hasil penelitian ini, peneliti memberikan beberapa rekomendasi yaitu (1) Pimpinana yayasan muhammadiyah, hendaknya penelitian ini digunakan sebagai salah satu pedoman dalam mengetahui nilai aset yang dimiliki sekolah; (2) Kepala Sekolah, hendaknya lebih meningkatkan pengelolaan atau manajemen aset yang dimiliki guna mencapai tujuan sekolah; (3) Wakasek dibidang Sarpras, hendaknya memahami berbagai aset yang dimiliki sekolah agar dalam proses pendataan aset dapat dikelompokan dengan baik; (4) Peneliti lain, diharapkan dapat mengembangkan instrumen penaksiran nilai aset dengan memberikan beberapa format yang diperlukan lebih spesifik sebagai sarana penelitian disekolah lainnya.

\section{DAFTAR RUJUKAN}

Amalia, D. (2017). Pengertian dan Jenis-Jenis Aktiva dalam Akuntansi, (Online), (https://www.jurnal.id/id/ blog/2017/pengertian-dan-jenis-jenis-aktiva-dalam-akuntansi), diakses 16 februari 2018.

Arikunto, S. (2010). Prosedur Penelitian Suatu Pendekatan Praktik. Jakarta: Rineka Cipta.

Bastian, I. (2007). Akuntansi Pendidikan. Jakarta: PT. Erlangga.

Istijanto. (2006). Riset Sumber Daya Manusia. Jakarta: Gramedia Pustaka Utama. 
Juharyanto \& Sultoni. (2019). Kepemimpinan Kepala Sekolah dalam Penguatan Peran Multi-Stakeholders Forum: Masalah dan Strategi Solutif Peningkatan Mutu SD - SMP Satu Atap di Daerah Terpencil. Sekolah Dasar: Kajian Teori Dan Praktik Pendidikan, 82(01), 1-10.

Juharyanto. (2017). Kepemimpinan unggul Kepala Sekolah Dasar Daerah Terpencil (Studi Multisitus pada Sekolah Dasar di Kabupaten Bondowoso). Jurnal Sekolah Dasar, 1(Tahun 26). http://jurnal.fip.um.ac.id/sekolahdasar.

Jeeva. S. A. and Ahmed Mohsen Salem Baswaid. (2014). A Strategic Procurement Concept for Physical Asset Management Framework. Proceedings of the 2014 International Conference on Industrial Engineering and Operations Management Bali, Indonesia, January 7 - 9, 2014. http//iieom.org/ieom2014/pdfs/557.pdf.

Kieso, D. E., \& Weygandt, J.J. (1995). Akuntansi Intermediate Edisi Ketujuh Jilid 2. Jakarta: Binarupa Aksara.

Lumbantorum, S. (2006). Akuntansi pajak. Jakarta: PT Gramedia Widiasarana Indonesia.

Maxmanroe. (2019). Manajemen Aset, (Online), (https:/www.maxmanroe.com/vid/manajemen/manajemen-aset. html), diakses 5 juli 2019.

Nainggolan, P. (2005). Akuntansi Keuangan Yayasan dan Lembaga Nirlaba Sejenis. Jakarta: PT. Raja Grafindo Persada.

Nasution, S. (1987). Metode Research. Bandung: PT.Jemmars.

Nugroho, B,A. (2014). Sistem Manajemen Aset Sekolah. Jurnal Informatika dan Multimedia, 6(1). https://ojs. poltekkediri.ac.id/index.php/JIM/article/ view/15/14.

Pedoman Teknis Pengelolaan Barang Milik Daerah. (2008). Peraturan Menteri Dalam Negeri Nomor 17 Tahun 2007. Bandung: Fokus Media

Prihadi \& Wahyu, A. (1994). Akuntansi 1 Sekolah Menengah Umum. Surakarta: PT. Pabelan.

Setyadin, B. (2005). Dasar-Dasar Penelitian Ilmiah. Malang: Lembaga Penelitian Universitas Negeri Malang.

Sugiama, A. G. (Ed). (2013). Manajemen Aset Pariwisata, Guardaya Intimarta. Bandung: Polban

Sugiyono. (2015). Metode Penelitian Kuantitatif, Kualitatif, dan R\&D. Bandung: Alfabeta

Sunandar, A. (2016). Manajemen Aset Sekolah. Malang: Universitas Negeri Malang.

Sutrisno. (1986). Akuntansi. Malang: PT. Citra Prestasi.

Tahir, M. (2011). Pengantar Metodologi Penelitian Pendidikan. Makassar: Universitas Muhammadiyah Makasar. Tim Dosen UM. (2017). Pedoman Penulisan Karya Ilmiah. Malang: Universitas Negeri Malang.

Wahjosumidjo. (2011). Kepemimpinan Kepala Sekolah. Jakarta: Raja Grafindo Persada.

Yusuf, M. (2013). Langkah Pengelolaan Aset Daerah. Jakarta: Salemba Empat.

Undang-Undang Republik Indonesia Nomor 20 Tahun 2003 Tentang Sistem Pendidikan Nasional (Sisdiknas). 2003. Bandung: Citra Umbaran.

Undang- Undang Republik Indonesia Nomor 16 Tahun 2001 Mengenai Yayasan, (Online), (www.fk.unair.ac.id/ pdfiles/), diakses 31 maret 2017. 